\title{
PYRACLOSTROBIN SUPPRESSED Ganoderma BASAL STEM ROT (BSR), PROMOTED PLANT GROWTH AND INDUCED EARLY

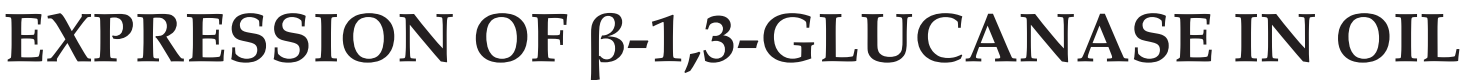 PALM (Elaeis guineensis)
}

\author{
NURFAEZAH SAID*; DZOLKHIFLI OMAR*; ABBAS NASEHI** and MUI-YUN WONG**
}

\begin{abstract}
Pyraclostrobin, a new group of fungicide, was evaluated on its efficacy to suppress G. boninense as well as its effect on oil palm physiology, growth promotion, and induction of defense-related gene, $\beta$-1,3-glucanase. Hexaconazole was also used as a positive control. In vitro, the best inhibitory result was achieved using pyraclostrobin at $0.75 \mu \mathrm{g}$ a.i. $\mathrm{ml}^{-1}$ with percentage inhibition of radial growth (PIRG) of $80 \%$, followed by pyraclostrobin at $0.50 \mu \mathrm{g}$ a.i. $\mathrm{ml}^{-1}$ (PIRG 73\%) and hexaconazole at $0.15 \mu \mathrm{g}$ a.i. $\mathrm{ml}^{-1}$ (PIRG 73\%). Probit analysis also indicated that emulsifiable concentrate $(E C)$ values of pyraclostrobin towards $\mathrm{G}$. boninense mycelial growth were $0.25 \mu \mathrm{g}$ a.i. $\mathrm{ml}^{-1}$ for $E C_{50}$ and $0.58 \mu \mathrm{g}$ a.i. $\mathrm{ml}^{-1}$ for $E C_{75}$, which were further tested in vivo. In general, in vivo results indicated that the oil palm seedlings treated with pyraclostrobin at $E C_{75}$ had significantly lower basal stem rot (BSR) infection, higher plant growth, and positive effects on plant physiology compared to pyraclostrobin at $E C_{50}$ and were comparable to hexaconazole. Moreover, gene expression of $\beta-1,3-$ glucanase in the seedlings treated with pyraclostrobin at $E C_{75}$ indicated the highest level at the early stage. These results suggest that pyraclostrobin at $E C_{75}$ was able to suppress $B S R$ with high efficacy and significantly improved plant growth.
\end{abstract}

Keywords: induced resistance, plant height, photosynthesis rate, strobilurin.

Date received: 23 September 2018; Sent for revision: 12 October 2018; Received in final form: 28 January 2019; Accepted: 30 April 2019.

\section{INTRODUCTION}

Oil palm (Elaeis guineensis Jacq.) is the world's highest yielding oil crop and its production is five times greater per unit of land than any other oil crop (Oettli et al., 2018). Malaysia is the second largest palm oil producing country which contributed about $30 \%$ of the world total palm oil of 58.31

\footnotetext{
* Department of Plant Protection, Faculty of Agriculture, Universiti Putra Malaysia,

43400 UPM Serdang, Selangor, Malaysia.

** Institute of Plantation Studies, Universiti Putra Malaysia, 43400 UPM Serdang, Selangor, Malaysia.

E-mail: muiyun@upm.edu.my
}

million tonnes (MPOB, 2016). The total oil palm planted areas of Malaysia was estimated at 5.74 million hectares in 2016, including mature plantings (5 million hectares) and immature plantings (0.74 million hectares) (MPOB, 2016).

Basal stem rot (BSR) has been identified as the major disease constraint to sustainable oil palm production in South-east Asia. BSR is caused by the genus Ganoderma and the most virulent species is G. boninense (Sahebi et al., 2015; Idris et al., 2003). Losses begin to have financial effect when the disease affects more than $10 \%$ of the stand (Hasan and Turner, 1998). On average, there is a decline of fresh fruit bunch (FFB) of $0.16 t \mathrm{tha}^{-1}$ for every 
palm lost, and when the stand declined by $50 \%$, the average FFB yield reduction is 35\% (Subagio and Foster, 2003).

Several control methods such as cultural, chemical and biological methods have been used for the control of BSR. Chemical application is one of the ways to prevent BSR spread. In this respect, BSR infections were treated by the fungicide hexaconazole applied by hand-knock pressure injection, resulting in $70 \%$ survival rate of infected oil palm (Idris, 2007). Strobilurin is one of the most important classes of agricultural fungicide. It was first developed from natural fungicidal derivatives, such as strobilurin A, oudemansin A, and myxothiazol A. Starting with a bio-fungicide compound, this chemical has been extensively studied for more than 20 years which led to synthetic fungicide production. Strobilurin has now represented about one-fifth of global fungicides (USD 7.3 billion) (McDougall, 2004). Pyraclostrobin from the group of strobilurin has shown very effective control against several plant pathogenic fungi from the phyla Ascomycota and Basidiomycota (Bartlett et al., 2002). This broad spectrum fungicide demonstrated fungistatic effect, plant health promoting, and induced resistance activities by inducing pathogenesis-related (PR) proteins which act as a protective barrier against invading pathogens by collecting at the infection sites and act to decrease susceptibility of plants.

Plants have the ability to develop mechanisms to combat pathogens and pests by activating major defense mechanisms after detection of detrimental organism distressing to their survival (Cota et al., 2007), such as oil palm affected by G. boninense (Govender et al., 2017; Tan et al., 2016a,b; Sargolzaei et al., 2016; Kwan et al., 2015; Tan et al., 2015; 2013; Sathyapriya et al., 2012). Defense mechanisms in plants include the production of reactive oxygen species (ROS), cell wall strengthening, phytoalexin biosynthesis and the accumulation of defenserelated proteins such as PR proteins (Rivera et al., 2002). PR proteins may be induced in various tissues in response to a variety of stresses or stress-related plant hormones, including ethylene, osmotic stress, wounding, drought, high salinity, and abscisic acid (Horvath et al., 1998; Ponstein et al., 1994). Most PR and related proteins are induced through the action of the signaling compounds salicylic acid, jasmonic acid, or ethylene, and possess anti-microbial activities in vitro (Van Loon and Bakker, 2003). The $\beta$-1,3-glucanase genes are one of three structurally distinct classes of protein from PR-2 group (Stintzi et al., 1993). These genes are hydrolytic enzymes which are able to hydrolyze $\beta-1,3$ glucan of cell wall for several genera of fungi (Hara et al., 1997). Induction of $\beta$-1,3-glucanases have been demonstrated in many plant-fungal pathogen interactions. The enzymes are able to degrade the cell wall of the pathogen or disrupt its deposition, thus led to pathogen death.
They also release cell wall fragments that act as elicitors of active host defense response (Keen and Yoshikawa, 1983). Yeoh et al. (2012) reported that gene expression of $\beta-1,3$-glucanases in oil palm was suppressed during infection of G. boninense and increased by application of biological control agent, Trichoderma harzianum.

So far, there is no single or combination of method(s) that are effective for the control of BSR in the field (Wong et al., 2012; Hushiarian et al., 2013; Naher et al., 2013; Chen et al., 2017; Azura et al., 2016). Thus, efforts to find effective methods with high efficacy and sustainability to control the disease are still on-going. Pyraclostrobin has shown high potential against fungal diseases. Therefore, the objectives of the present study were to evaluate the use of pyraclostrobin to suppress growth of $G$. boninense in vitro and in vivo as well as its effect on plant physiology, growth promotion, and induction of defense-related gene, $\beta$-1,3-glucanase.

\section{MATERIALS AND METHODS}

\section{In vitro Assessment of Anti-fungal Activity of Pyraclostrobin}

Fungal isolate. A pure culture of $G$. boninense isolate USR/Q was obtained from the fungal culture collection, Department of Plant Protection, Faculty of Agriculture, Universiti Putra Malaysia (UPM), Selangor, Malaysia. The isolate was maintained on malt extract agar (MEA, Difco, USA) at room temperature $\left(25 \pm 2^{\circ} \mathrm{C}\right)$ for further studies.

Fungicides. In all experiments, hexaconazole was used as positive control as it is recommended for the control of BSR in the field (Idris, 2007). Fungicide formulations of pyraclostrobin $250 \mathrm{~g}$ active ingredient/litre emulsifiable concentrate (EC) (F500 250 EC Cabrio, BASF Hellas) and hexaconazole 50 $\mathrm{g}$ active ingredient/litre SC (5SC Anvil, Sygenta) were used in these experiments. Stock solutions per well were prepared for pyraclostrobin $(0.25,0.50$, and $0.75 \mu \mathrm{g}$ a.i. $\left.\mathrm{ml}^{-1}\right)$ and hexaconazole $(0.05,0.10$, and $0.15 \mu \mathrm{g}$ a.i. $\mathrm{ml}^{-1}$ ) which were equal to 10,20 and $30 \mu \mathrm{l}$ for both fungicides per $10 \mathrm{ml}$ of MEA. For pyraclostrobin, $0.25 \mu \mathrm{g}$ a.i. $\mathrm{ml}^{-1}$ is the recommended rate by the manufacturer, while 0.50 and $0.75 \mu \mathrm{g}$ a.i. $\mathrm{ml}^{-1}$ were the increasing rates used. For hexaconazole, $0.10 \mu \mathrm{g}$ a.i. $\mathrm{ml}^{-1}$ is the recommended rate by the manufacturer, and 0.05 and $0.15 \mu \mathrm{g}$ a.i. $\mathrm{ml}^{-1}$ were the decreasing and increasing rates, respectively.

Mycelial growth assay. In this experiment, well diffusion method was used to assess the mycelial growth. For this purpose, individual agar plugs of 7-day old culture of G. boninense isolate USR/Q were taken using a cork borer (8 $\mathrm{mm}$ diameter) and 
placed $2 \mathrm{~cm}$ away from the centre of $9 \mathrm{~cm}$ Petri dishes containing $10 \mathrm{ml}$ of MEA (one plug per Petri dish). A hole was also made using the same size cork-borer $2 \mathrm{~cm}$ away from the centre for the seven following treatments: $\mathrm{T} 1(10 \mu \mathrm{l}$ of double distilled water as a negative control), T2 (10 $\mu$ l of pyraclostrobin), T3 (20 $\mu \mathrm{l}$ of pyraclostrobin), T4 (30 $\mu$ l of pyraclostrobin), T5 (10 $\mu \mathrm{l}$ of hexaconazole), T6 (20 $\mu \mathrm{l}$ of hexaconazole), and T7 (30 $\mu$ l of hexaconazole). Seven replicates were used for all treatments. The treated Petri dishes were sealed with parafilm and incubated at $24^{\circ} \mathrm{C}$ in the dark. Radial growth of mycelia ( $\mathrm{mm}$ ) was measured separately after the fungus was fully grown in the negative control plates (14 days). Pyraclostrobin concentrations required to inhibit mycelial growth at $50 \%\left(\mathrm{EC}_{50}\right)$ and $75 \%\left(\mathrm{EC}_{75}\right)$ of the level observed for the control were estimated using Polo Plus software. PIRG of the fungal pathogen was calculated using the formula below (Sadrati et al., 2013):

$$
\mathrm{PIRG}=\frac{\mathrm{A}-\mathrm{B}}{\mathrm{A}} \times 100
$$

A - radius of the pathogen in control plate.

$\mathrm{B}$ - radius of the pathogen in dual culture plate.

In this experiment, agar plugs which did not show any growth in the treated plates were transferred to freshly prepared MEA without fungicides in order to determine whether the activity of the corresponding active ingredient was fungistatic or fungicidal. The plates were incubated at $24^{\circ} \mathrm{C}$ in the dark, and radial growth of mycelia was checked daily until 14 days. Experiments were conducted in triplicate for each fungicide.

\section{Statistical Analysis}

Statistical analysis was carried out using SAS 9.2 (SAS Institute Inc., Cary, NC, USA). Significant differences between means of PIRG were determined by Fisher's test at a significance level of 0.05 and multiple mean comparisons were done using Least Significant Different (LSD).

\section{In vivo Assessment of Anti-fungal Activity of Pyraclostrobin}

Fungal inoculum. The inoculum of G. boninense isolate USR/Q was prepared using rubber wood blocks (RWB) with the size of $12 \times 6 \times 6 \mathrm{~cm}$ following the method described by Teh and Sariah (1999) with slight modifications. The blocks were washed with running tap water, autoclaved at $121^{\circ} \mathrm{C}$ for 20 min, and then kept cool overnight. Each block was put in a heat-resistance polypropylene bag $(15 \mathrm{~cm}$ length $\times 33 \mathrm{~cm}$ height $\times 0.05 \mathrm{~mm}$ thick) and $100 \mathrm{ml}$ of molten MEA was poured onto each block. The open end of polypropylene bags were closed using caps and necks made of polyvinyl chloride (PVC), and sponges were put in the holes at the top of caps. The polypropylene bags containing RWB were autoclaved at $121^{\circ} \mathrm{C}$ for $30 \mathrm{~min}$. RWB were cooled and the solidified MEA were crushed and scattered around the RWB without opening the caps. Then, they were kept overnight at room temperature. Each RWB was inoculated with three 7-day old mycelial plugs (8 $\mathrm{mm}$ diameter) of $\mathrm{G}$. boninense in a laminar airflow cabinet. The inoculated RWB were incubated in the dark chamber at $26^{\circ} \mathrm{C}$ to $30^{\circ} \mathrm{C}$ for 20 days until the mycelia covered all surfaces of the blocks.

Preparation of planting medium. Sterilised soil (3:2:1 ratio of topsoil, peat and sand) was prepared in a glasshouse at Ladang 2, UPM. The soil was sieved before mixing using a soil mixer. The mixed soil was moistened to $60 \%$ and then sterilised for 1.5 $\mathrm{hr}$ at $82^{\circ} \mathrm{C}$ by a soil steriliser. The sterilised soil was then cooled in a clean area. For each pot $(28 \times 28 \times$ $30 \mathrm{~cm}$ ), $3 \mathrm{~kg}$ of sterilised soil was used.

Experimental design. A total of 156 3-month old oil palm seedlings (DxP) were used in these experiments. The experiments were divided into two groups where four blocks were assigned for nondestructive sampling and one block for destructive sampling. The experiment for non-destructive sampling was arranged in randomised complete block design (RCBD) with four blocks, six treatments, and four replications (total 96 seedlings). A total of 24 seedlings were used in each block. Destructive sampling was arranged in completely randomised design (CRD) with six treatments and 10 replications (total 60 seedlings) where two seedlings from each treatment were harvested every two months for the study of defense-related gene expression. The six treatments used in these experiments were as follow: T1 (sterilised RWB as healthy control), T2 (infected RWB as disease control), T3 (sterilised RWB + 0.25 $\mu \mathrm{g} \mathrm{ml} \mathrm{l}^{-1}$ of pyraclostrobin as pyraclostrobin control), T4 $\left(0.25 \mu \mathrm{g} \mathrm{ml}^{-1}\right.$ of pyraclostrobin + infected RWB as $\mathrm{EC}_{50}$ treatment), T5 $\left(0.5 \mu \mathrm{g} \mathrm{ml}^{-1}\right.$ of pyraclostrobin + infected RWB as $\mathrm{EC}_{75}$ treatment), and T6 $(0.1 \mu \mathrm{g}$ $\mathrm{ml}^{-1}$ of hexaconazole according to manufacturer's recommendation as positive control).

Fungicide application. Each treatment was arranged in $2 \times 1 \mathrm{~m}$ area and applied with 1.5 litres of required fungicides or with tap water for healthy control seedlings. The fungicides were prepared in glass bottles wrapped with aluminum foil to avoid light reaction, and each mixture was added with $0.02 \%$ Tween 20 as adjuvant. The mixtures were prepared $1.5 \mathrm{hr}$ before application. The fungicides were sprayed in the morning using pneumatic pump sprayer with capacity of 6 litres, equipped with full cone nozzles, and each treatment was consistently applied at the same pressure and same height of nozzle. The fungicides were sprayed separately on 
the foliar of seedlings until runoff. To prevent the chemical from entering the soil, each pot was covered with plastic bag during spraying application. The seedlings were unwrapped and arranged back in the glasshouse when the chemicals were dried (about $1.5 \mathrm{hr}$ ). The seedlings were inoculated with G. boninense-colonised RWB using the sitting method on treatments $2,4,5$ and 6 . Treatments 1 (healthy control) and 3 (pyraclostrobin control) were inoculated with RWB without G. boninense. Sitting method was done by placing the seedling roots directly in contact with the fully colonised RWB in the pots and sterilised soil was added. This procedure was done three days after the application of fungicides. The procedure for spraying was repeated every two months which was in month 0 , $2,4,6$ and 8 . For month 0 , pre-treatment application of fungicide was done as a preventive application three days before the plants were inoculated with G. boninense.

\section{Assessment of Disease Development}

Disease incidence (DI) assessment of all treatments was calculated at eight intervals (months) using the following formula (Campbell and Madden, 1990):

$$
\text { DI }(\%)=\frac{\text { Number of infected seedlings }}{\text { Total number of assessed seedlings }} \times 100
$$

To evaluate the effectiveness of treatments in controlling disease, DI was compared with control treatment. Then, the data was plotted into disease progress curve. The area under disease progress curve (AUDPC) was generated by the following formula using Sigmaplot 8.0 software:

$$
\text { AUDPC }=\sum_{i}^{n-1}\left[\frac{Y_{i}+Y_{i+1}}{2}\right]\left[t_{i+1}-t_{i}\right]
$$

\section{where;}

$\mathrm{n}$ - number of assessments.

Yi - disease incidence.

ti - observation time.

Disease severity (DS) was rated using scoring 0-4 of foliage, root, and bole monthly (Breton et al., 2005). Scales for symptom were as follow: 0 = healthy plant, $1=$ appearance of yellowing at 3 or more leaves, 2 = appearance formation of white mycelia at seedling bole, 3 = appearance formation of button-like sporophore at the bole, and $4=$ dead plant. DS for foliar symptom was calculated using the following formula as described by Liu et al. (1995):

$$
\text { DS }(\%)=\frac{\begin{array}{c}
\text { Number of seedlings in the } \\
\text { rating } \times \text { rating number }
\end{array}}{\begin{array}{l}
\text { Total number of seedlings } \\
\text { assessed } \times \text { highest rating }
\end{array}} \times 100
$$

\section{Assessment of Plant Growth}

Plant height was measured using long measuring ruler from $1 \mathrm{~cm}$ above the soil level to the tip of the fully open leaves eight months after inoculation. The increment of plant height was determined by the difference between the height at final month and the beginning of experiment. At the end of experiment, the seedlings were split longitudinally to measure plant bole diameter using ruler. The fresh weight of the whole plant and root mass was quantified by weighing each on the electronic weighing scale (CDS 125, Mitutoyo Inc, Japan).

\section{Physiological Analysis}

Eight months after inoculation, photosynthesis rate was measured using infrared gas analyser LICOR 6400 Portable Photosynthesis System (IRGA: LICOR Inc., Lincoln, NE, USA) by placing leaf cuvette on the fully expanded leaf of third frond and set with optimal growth condition for oil palm at $1000 \mu \mathrm{mol} \mathrm{m} \mathrm{m}^{-2} \mathrm{~s}^{-1}$ photosynthetic photon flux density, $400 \mu \mathrm{mol} \mathrm{mol}^{-1} \mathrm{CO}_{2}, 30^{\circ} \mathrm{C}$ leaf temperature and $60 \%$ relative humidity. Quantum efficiency of photosystem II (QPS II) measurement was also taken using portable Chlorophyll Fluorescence meter-HANDY-FEA in the final month. Relative chlorophyll content was measured using chlorophyll meter (SPAD-502; Minolta, Osaka, Japan) to indicate chlorophyll status in the leaves eight months after inoculation. Three measurements were taken on both upper and below parts of the developed leaves. This procedure was applied to three leaves for each seedling and the data were averaged.

\section{Expression of Defense-related Gene $\beta-1,3-$ Glucanase}

Gene expression of $\beta$-1,3-glucanase was investigated in this experiment while glyceraldehyde3-phosphate dehydrogenase (GAPDH) was used as housekeeping gene (Kwan et al., 2016). For each treatment, destructive sampling of two seedlings harvested at 0, 2, 4, 6 and 8 months after inoculation was done. Root and bole tissues were sampled by a quick dip in the liquid nitrogen to preserve the integrity of RNA in the samples. The samples were brought to the laboratory and stored at $-80^{\circ} \mathrm{C}$ for further analysis. For month 0 , the seedlings were sampled four days after challenged with $G$. boninense. Samplings for 2, 4, 6 and 8 months after inoculation were done four days after treatment with fungicides.

\section{RNA Extraction}

Total RNA was extracted from each root sample using modified cetyltrimethylammonium bromide 
(CTAB) method. For this purpose, $3 \mathrm{~g}$ of bole and root tissue was ground in liquid nitrogen using RNAse-free mortar and pestle into very fine powder. Ground tissues were quickly transferred into a 50 $\mathrm{ml}$ polypropylene centrifuge tube containing $15 \mathrm{ml}$ of CTAB extraction buffer and added with equal volume of chloroform:isoamylalchohol (C:I) (24:1) and centrifuged at maximum speed for $5 \mathrm{~min}$. The upper layer was carefully transferred to a new $1.5 \mathrm{ml}$ microcentrifuge tube and added with one volume of phenol:chloroform:isoamylalcohol (P:C:I) (25:24:1) and centrifuged at maximum speed for $5 \mathrm{~min}$. This step was repeated twice until the clear white supernatant was produced. The final supernatant was transferred into a new $1.5 \mathrm{ml}$ microcentrifuge tube and adjusted to a final volume of $3 \mathrm{M} \mathrm{LiCl}$ before incubated on ice for $30 \mathrm{~min}$. The homogenate was centrifuged at maximum speed for $5 \mathrm{~min}$ before the clear supernatant was discarded. The pellet was dissolved in $5 \mathrm{ml}$ of diethypyrocarbonate (DEPC)treated water and one volume of C:I and centrifuged at maximum speed for $3 \mathrm{~min}$. The supernatant was transferred into a new $1.5 \mathrm{ml}$ microcentrifuge tube and RNA was precipitated by adding 0.1 volume of $3 \mathrm{M}$ sodium acetate at $\mathrm{pH} 5.2$ and 2.5 volume of $100 \%$ ethanol and was centrifuged at maximum speed for $3 \mathrm{~min}$. The resulting pellet was washed with $70 \%$ ethanol and air dried in the laminar airflow cabinet for $3 \mathrm{~min}$. The pellet was dissolved in $20 \mu \mathrm{l}$ DEPC-treated water and the integrity of RNA was examined using spectrophotometer at 230, 260 and $280 \mathrm{~nm}$. Total RNA was treated with DNase I (Qiagen, USA) according to the manufacturer's instructions. Nanodrop was used to quantify and determine the integrity and purity of total RNA obtained.

\section{Reverse Transcription-polymerase Chain Reaction (RT-PCR)}

Total RNA of control and treated samples were converted into complementary DNA (cDNA) using Quantitative Reverse Transcript cDNA synthesis kit following the manufacturer's instructions (Qiagen, USA). Briefly, $1 \mu \mathrm{g}$ of total RNA and $2 \mu \mathrm{l}$ 7X gDNA wipe buffer (provided in the kit) was transferred into $1.5 \mathrm{ml}$ microcentrifuge tube followed by adding DEPC-treated water to a total volume of $14 \mu \mathrm{l}$. The mixture was incubated in the incubation block at $42^{\circ} \mathrm{C}$ for $2 \mathrm{~min}$ and chilled on ice quickly. The reaction mixture was added with $4 \mu \mathrm{l}$ of $5 X$ Quantiscript RT buffer, $1 \mu \mathrm{l}$ of reverse transcriptase enzyme and the mixture was incubated at $42^{\circ} \mathrm{C}$ for $30 \mathrm{~min}$. Lastly, the reaction was heated at $95^{\circ} \mathrm{C}$ for $3 \mathrm{~min}$ to terminate the cDNA synthesis reaction and the cDNA was stored at $-20^{\circ} \mathrm{C}$ for further use. Primers used for PCR amplification of $\beta$-1,3-glucanase was Glu-F, 5' GTT TGC ACC TGG TGG AGT G-3' and Glu $-\mathrm{R}, 5^{\prime}$ ACT GCC CTT GAA GTG AGA GC -3'. The housekeeping GAPDH gene (GeneBank Accession No. DQ267444) was used as an endogenous control (Sathyapriya et al., 2012). PCR was performed using

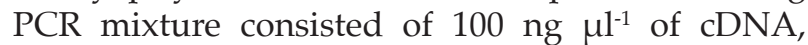
$0.1 \mu \mathrm{M}$ of each primer, $0.25 \mu \mathrm{M}$ dNTP, 1 X PCR buffer and $0.2 \mathrm{U}$ DNA polymerase (Fermentas, USA) in a total volume of $20 \mu \mathrm{l}$. Amplification was performed under the following conditions: one cycle of denaturation at $94^{\circ} \mathrm{C}$ for $1 \mathrm{~min}$, followed by 30 cycles of annealing at $94^{\circ} \mathrm{C}$ for $1 \mathrm{~min}$, gradient temperatures between $55^{\circ} \mathrm{C}$ and $60^{\circ} \mathrm{C}$ for $30 \mathrm{~s}$, extension $72^{\circ} \mathrm{C}$ for $1 \mathrm{~min}$, and final extension at $72^{\circ} \mathrm{C}$ for $7 \mathrm{~min}$. PCR was performed using T-Personal thermocycler (Biometra). PCR was performed to amplify $\beta$-1,3-glucanase and GAPDH genes with three replications for each treated and untreated samples. The amplified products were purified using QIAquick Gel Extraction Kit (QIAGEN) according to the manufacturer's instructions and sequenced by First BASE Laboratories Sdn Bhd, Malaysia.

\section{Gel Electrophoresis and Staining}

Visualisation of PCR products was done using gel electrophoresis. A quantity of $4 \mu \mathrm{l}(20$ ng) of PCR products was run in $1.7 \%$ agarose gel using $200 \mathrm{ml}$ fresh $1 \times$ TAE buffer $(40 \mathrm{mM}$ Tris, $20 \mathrm{mM}$ acetic acid and $1 \mathrm{mM}$ EDTA) at $75 \mathrm{~V}$ for $60 \mathrm{~min}$ at $25^{\circ} \mathrm{C}-28^{\circ} \mathrm{C}$. The gel was stained with ethidium bromide for $5 \mathrm{~min}$. The visualisation of PCR products was done using Gel Doc XR System (Bio-Rad) and repeated three times to avoid false results.

\section{Semi-quantitative Analysis of Gene Expression}

Gene expression levels in treated and untreated samples were measured by densitometric scanning performed using Molecular Imager Gel Doc XR System (Bio-Rad). Relative expression levels were calculated by Quantity One 1-D Analysis software 4.6.5 (Bio-Rad) according to the manufacturer's instructions. PCR products were run in $1.7 \%(\mathrm{w} / \mathrm{v})$ agarose gel $(1 \times$ TBE $)$ with a DNA mass standard marker (MassRulerTM DNA Ladder, Fermentas). The net intensity of the background subtracted pixel values in the band rectangle. The gel images were scanned to determine the net intensities of target bands. The net intensity data for $\beta$-1,3-glucanase was normalised using housekeeping gene (GAPDH) at $0 \mathrm{hr}$. Corrected values were calculated by dividing the net intensity volume of $\beta$-1,3-glucanase value by its corresponding housekeeping gene (GAPDH) value multiply by the highest GAPDH net intensity volume. Normalised values were calculated by setting the $0 \mathrm{hr}$ corrected values equal to 1.0 and subsequently corrected values were divided by the $0 \mathrm{hr}$ values (Thanseem et al., 2005). 


\section{Statistical Analysis}

The data were subjected to analysis of variance procedure (ANOVA) using Statistical Analysis System (SAS) version 9.1 (SAS Institute Inc., Cary, NC, USA). The mean comparison was separated by LSD with 5\% significance level.

\section{RESULTS}

\section{In vitro Assessment of Anti-fungal activity of Pyraclostrobin}

Mycelial growth assay. Mycelial growth of G. boninense was restricted by both pyraclostrobin and hexaconazole 14 days after inoculation. Multiple mean comparisons indicated significant differences between both fungicides at different concentrations (Figure 1). The highest inhibitory effect was achieved by $\mathrm{T} 4$ (30 $\mu \mathrm{l}$ of pyraclostrobin) (PIRG $80 \%)$, followed by T3 (20 $\mu$ l of pyraclostrobin) and T7 (30 $\mu$ l of hexaconazole) (PIRG 73\% for both), T6 (20 $\mu$ l of hexaconazole) (PIRG 64\%), T2 (10 $\mu \mathrm{l}$ of pyraclostrobin) (PIRG 53\%), and T5 (10 $\mu$ l of hexaconazole) (PIRG 50\%). T1 (Control) did not show any mycelial inhibition (Figure 2).

Probit analysis and anti-fungal activity. Probit analysis indicated that EC values of pyraclostrobin towards G. boninense mycelial growth were 0.25 $\mu \mathrm{g}$ a.i. $\mathrm{ml}^{-1}$ for $\mathrm{EC}_{50}$ and $0.58 \mu \mathrm{g}$ a.i. $\mathrm{ml}^{-1}$ for $\mathrm{EC}_{75}$. Anti-fungal activity of both pyraclostrobin and hexaconazole against $G$. boninense indicated their fungistatic activities which were observed by the slow rate of mycelial growth by sub-culturing mycelia from the adjacent edge of treated plates into new plates compared to control plates.
In vivo Assessment of Anti-fungal Activity of Pyraclostrobin

Assessment of disease development. BSR disease developed rapidly across months in control plants and steadily in treated and infected seedlings (Figure $3)$. DI started to appear in plants of T2 (Control) and T6 (0.10 $\mu$ g a.i. $\mathrm{ml}^{-1}$ hexaconazole) at month $5(6.25 \%$ for both) with no significant difference between both treatments. Meanwhile, DI on plants of T4 (0.25 $\mu$ g a.i. $\mathrm{ml}^{-1}$ pyraclostrobin) and T5 (0.50 $\mu \mathrm{g}$ a.i. $\mathrm{ml}^{-1}$ pyraclostrobin) were first detected at month 6 (12.50\% and $8.25 \%$, respectively). DI of T2 (positive control) plants revealed the fastest increment and had the highest DI of $93.75 \%$ while DI for T4, T5 and T6 plants indicated delayed disease infection on oil palm seedlings and had low DI of $47.75 \%$, $47.75 \%$ and $43.75 \%$ respectively, with no significant difference at month 8 .

Similarly, DS also indicated an increasing trend across months in both treated and untreated infected seedlings (Figure 4). Treatments using fungicides showed disease progress that was slower compared to those of untreated control seedlings. Slow progress of DS on fungicide-treated seedlings started from month 6 until month 8 . At month 5, DS for plants of T2 and T6 were $24.65 \%$ and $24.33 \%$, respectively, with no significant difference. At month 6, DS for plants of T2 $(31.25 \%), \mathrm{T} 4(31.25 \%)$ and T6 $(34.75 \%)$ indicated no significant difference while DS for plants of T5 $(25.00 \%)$ was significantly lower. DS of the infected seedlings of all treatments showed no significant difference at month 7 while at month 8 , there were significant differences among the treatments where T2 plants showed the highest DS $(89.15 \%)$, followed by T4 $(55.64 \%)$, and T6 $(46.24 \%)$, and T5 (32.62\%).

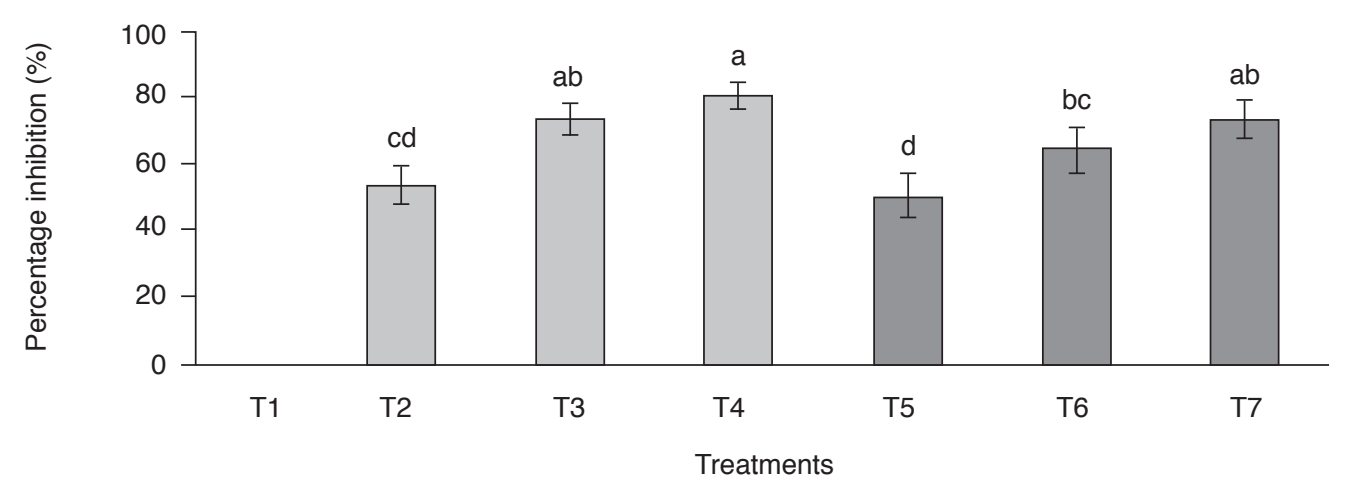

Figure 1. Percentage inhibition of radial growth (PIRG) of Ganoderma boninense mycelia by pyraclostrobin and hexaconazole 14 days after inoculation. The treatments are as follow: T1 (10 $\mu$ l of double distilled water as a negative control), T2 (10 $\mu$ l of pyraclostrobin), T3 (20 $\mu$ l of pyraclostrobin), T4 (30 $\mu$ l of pyraclostrobin), T5 (10 $\mu$ l of hexaconazole), T6 (20 $\mu$ l of hexaconazole), and T7 (30 $\mu$ l of hexaconazole). Means with same letter are not significantly different $(P \leq 0.001)$ by Least Significance Different (LSD). 


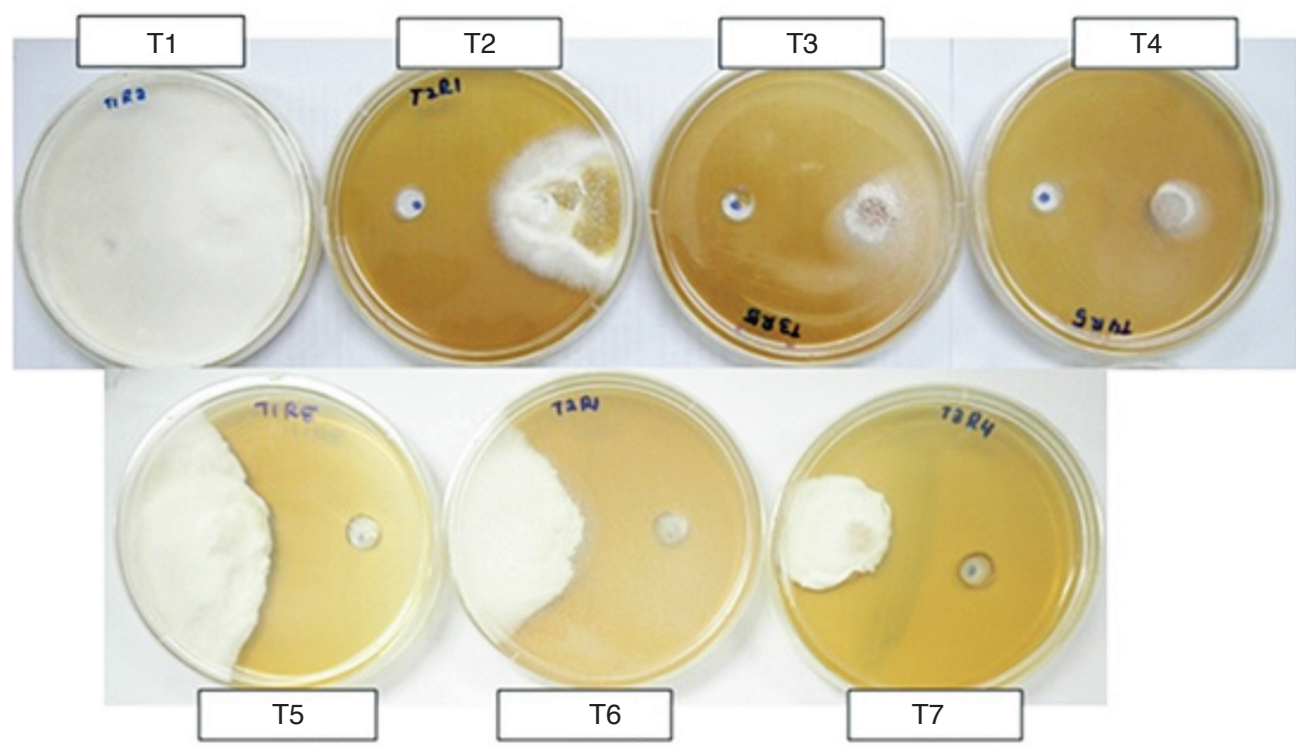

Figure 2. In vitro test of Ganoderma boninense towards pyraclostrobin and hexaconazole 14 days after inoculation. The treatments are as follow: T1 (10 $\mu$ l of double distilled water as a negative control), T2 (10 $\mu$ l of pyraclostrobin), T3 (20 $\mu$ l of pyraclostrobin), T4 (30 $\mu$ l of pyraclostrobin), T5 (10 $\mu$ l of hexaconazole), T6 (20 $\mu$ l of hexaconazole), and T7 (30 $\mu$ l of hexaconazole).

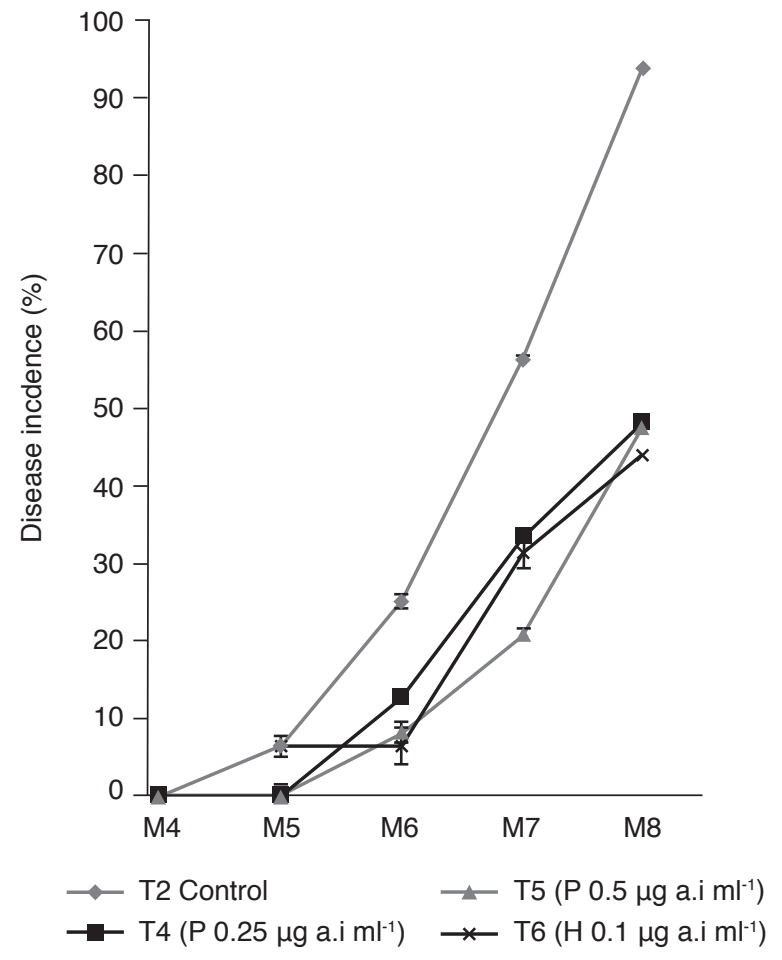

Figure 3. Percentage of disease incidence (DI) in oil palm seedlings pre-treated with fungicides and inoculated with Ganoderma boninense at eight months after inoculation. The treatments are as follow: T2 [G. boninense infected rubber wood blocks (RWB) as disease control], T4 $\left(0.25 \mu \mathrm{g} \mathrm{ml}^{-1}\right.$ of pyraclostrobin + G. boninense infected RWB as $E C_{50}$ treatment), T5 (0.5

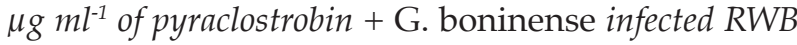
as $E C_{75}$ treatment $)$, and $\mathrm{T} 6\left(0.1 \mu \mathrm{g} \mathrm{ml} \mathrm{l}^{-1}\right.$ of hexaconazole + G. boninense infected RWB as positive control).

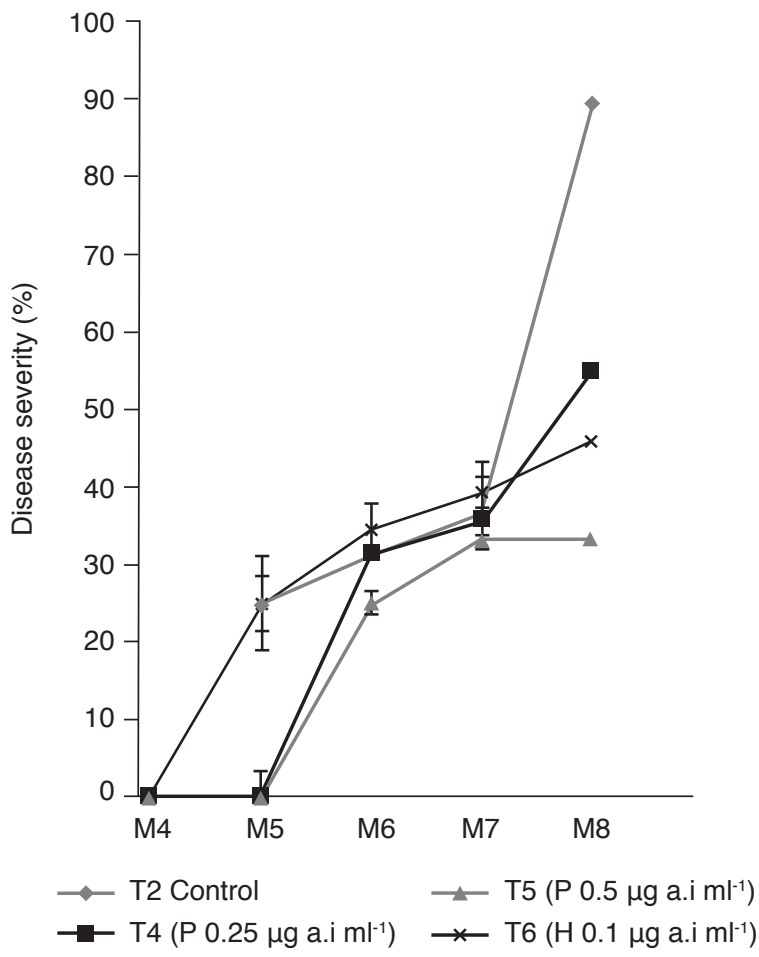

Figure 4. Percentage of disease severity (DS) in oil palm seedlings pre-treated with fungicides and inoculated with Ganoderma boninense at eight months after inoculation. The treatments are as follow: T2 [G. boninense infected rubber wood blocks (RWB) as disease control], T4 $\left(0.25 \mu \mathrm{g} \mathrm{ml^{-1 }}\right.$ of pyraclostrobin $+\mathrm{G}$. boninense infected $R W B$ as $E C_{50}$ treatment), T5 $(0.5 \mu \mathrm{g}$ $\mathrm{ml}^{-1}$ of pyraclostrobin $+G$. boninense infected RWB as $E_{75}$ treatment $)$, and $\mathrm{T} 6\left(0.1 \mu \mathrm{g} \mathrm{ml}^{-1}\right.$ of hexaconazole $+\mathrm{G}$. boninense infected RWB as positive control). 
Eight months after inoculation, seedlings pretreated with T5 showed the lowest AUDPC value of 18.63, followed by plants of T4 (29.33) and T6 (40.32) (Table 1). There was significant difference between AUDPC of T4 and T5 plants with control (T2) (71.88). AUDPC for plants of T6 had no significant difference from those of $\mathrm{T} 2$ plants. As expected, the control seedlings (T2) indicated the fastest increment of disease with DI of $93.75 \%$, DS of $89.15 \%$, and AUDPC of 71.88.

\section{Assessment of Plant Growth}

Plant height and bole diameter. The effect of pyraclostrobin on plant height and bole diameter of oil palm seedlings are shown in Table 2. Plants of T2 indicated the lowest increment of plant height $(20.50$ $\mathrm{cm}$ ) with no significant difference with plants of T4 $(24.44 \mathrm{~cm})$. There was also no significant difference between plants of T5 $(30.50 \mathrm{~cm}), \mathrm{T} 6(30.44 \mathrm{~cm})$, and T1 $(30.88 \mathrm{~cm})$ that showed moderate increment of height. T3 plants indicated the highest increment in plant height $(36.88 \mathrm{~cm})$ compared to $\mathrm{T} 1(30.88 \mathrm{~cm})$ plants as well as other treatments.

For bole diameter, plants of T2 and T4 demonstrated the smallest bole diameter (2.39 and $2.46 \mathrm{~cm}$, respectively) with no significant difference between them. A moderate bole diameter was observed in plants of T5 $(2.85 \mathrm{~cm})$ and T6 $(2.71 \mathrm{~cm})$ compared to T1 and T3. Plants of T1 and T3 indicated the highest bole diameter $(2.93 \mathrm{~cm})$.

Fresh weight and root mass. The effect of pyraclostrobin on fresh weight and root mass are shown in Table 2. There were significant differences in fresh weight between the treatments. The highest fresh weight was in T3 plants $(330.63 \mathrm{~g})$ followed by T1 plants $(288.13 \mathrm{~g})$. Plants of T5 $(240.63 \mathrm{~g})$ and T6 (217.13 g) indicated moderate fresh weight with no significant difference between them. The lowest fresh weight was recorded in T2 (174.38 g) and $\mathrm{T} 4(170.00 \mathrm{~g})$ plants with no significant difference between them.

The effect on root mass demonstrated similar pattern with fresh weight (Table 2). Plants of T3 showed the highest root mass (136.25 g) compared to other treatments. Plants of T1 had moderate root mass (114.69 g) followed by plants of T5 $(96.88 \mathrm{~g})$ and T6 (90.00 g). The lowest root mass values were observed in plants of T4 (63.75 g) and T2 (59.63 g) with no significant difference between them.

\section{Physiological Analysis}

Photosynthesis rate. The highest photosynthesis rate was observed in $\mathrm{T} 4$ plants $\left(4.95 \mu \mathrm{M} \mathrm{CO}_{2} \mathrm{~m}^{-2}\right.$

TABLE 1. AREA UNDER DISEASE PROGRESS CURVE (AUDPC) OF OIL PALM SEEDLINGS PRE-TREATED WITH FUNGICIDES AND INOCULATED WITH Ganoderma boninense AT EIGHT MONTHS AFTER INOCULATION

\begin{tabular}{ccc}
\hline Treatments $^{\mathrm{a}}$ & Application dose $\left(\mu \mathrm{g} \mathrm{a.i.} \mathbf{~ m l}^{-1}\right)$ & AUDPC $^{\mathrm{b}, \mathrm{c}}$ \\
\hline T2 & Water & $71.88 \mathrm{a}$ \\
T4 & 0.25 & $29.13 \mathrm{~b}$ \\
T5 & 0.50 & $18.63 \mathrm{~b}$ \\
T6 & 0.10 & $40.63 \mathrm{ab}$ \\
\hline
\end{tabular}

Note: ${ }^{a}$ The treatments are as follow: T2 [G. boninense infected rubber wood blocks (RWB) as disease control], T4 $\left(0.25 \mu \mathrm{g} \mathrm{ml} \mathrm{H}^{-1}\right.$ of pyraclostrobin + G. boninense infected $\mathrm{RWB}$ as $\mathrm{EC}_{50}$ treatment $)$, $\mathrm{T} 5\left(0.5 \mu \mathrm{g} \mathrm{ml}^{-1}\right.$ of pyraclostrobin + G. boninense infected RWB as $\mathrm{EC}_{75}$ treatment), and $\mathrm{T} 6\left(0.1 \mu \mathrm{g} \mathrm{ml}^{-1}\right.$ of hexaconazole + G. boninense infected RWB as positive control).

${ }^{\mathrm{b}}$ AUDPC - area under disease progress curve.

'Means with same letter in the same column are not significantly different $(\mathrm{P} \leq 0.05)$ by Least Significance Different (LSD).

TABLE 2. ASSESSMENT OF PLANT GROWTH OF OIL PALM SEEDLINGS TREATED WITH FUNGICIDES, INOCULATED AND UNINOCULATED WITH Ganoderma boninense AT EIGHT MONTHS AFTER INOCULATION

\begin{tabular}{|c|c|c|c|c|c|}
\hline Treatments $^{a}$ & Oil palm status & $\begin{array}{l}\text { Increment of } \\
\text { height }(\mathrm{cm})^{\mathrm{b}}\end{array}$ & $\begin{array}{l}\text { Bole diameter } \\
(\mathrm{cm})^{\mathrm{b}}\end{array}$ & $\begin{array}{c}\text { Fresh weight } \\
(\mathrm{g})^{\mathrm{b}}\end{array}$ & $\begin{array}{l}\text { Root mass } \\
(\mathrm{g})^{\mathrm{b}}\end{array}$ \\
\hline $\mathrm{T} 1$ & Healthy & $30.88 b$ & $2.93 a$ & $288.13 b$ & $114.69 \mathrm{~b}$ \\
\hline $\mathrm{T} 3$ & & $36.88 \mathrm{a}$ & $2.93 a$ & $330.63 a$ & $136.25 a$ \\
\hline $\mathrm{T} 2$ & Disease/infected & $20.50 c$ & $2.39 \mathrm{c}$ & $174.38 \mathrm{~d}$ & $59.63 d$ \\
\hline $\mathrm{T} 4$ & & $24.44 \mathrm{c}$ & $2.46 \mathrm{c}$ & $170.00 d$ & $63.75 \mathrm{~d}$ \\
\hline $\mathrm{T} 5$ & & $30.50 \mathrm{~b}$ & $2.85 \mathrm{ab}$ & $240.63 c$ & $96.88 \mathrm{bc}$ \\
\hline $\mathrm{T} 6$ & & $30.44 b$ & $2.71 b$ & $217.13 \mathrm{c}$ & $90.00 \mathrm{c}$ \\
\hline
\end{tabular}

Note: ${ }^{a}$ The treatments are as follow: T1 [sterilised rubber wood blocks (RWB) as healthy control], T2 (G. boninense infected RWB as disease control), T3 (sterilised RWB $+0.25 \mu \mathrm{g} \mathrm{ml}^{-1}$ of pyraclostrobin as pyraclostrobin control), T4 $\left(0.25 \mu \mathrm{g} \mathrm{ml} l^{-1}\right.$ of pyraclostrobin $+G$. boninense infected RWB as $\mathrm{EC}_{50}$ treatment), $\mathrm{T} 5\left(0.5 \mu \mathrm{g} \mathrm{ml}^{-1}\right.$ of pyraclostrobin + G. boninense infected RWB as $\mathrm{EC}_{75}$ treatment), and $\mathrm{T} 6\left(0.1 \mu \mathrm{g} \mathrm{ml}^{-1}\right.$ of hexaconazole as positive control).

${ }^{b}$ Means with same letter in the same column are not significantly different $(\mathrm{P} \leq 0.001)$ by Least Significance Different (LSD). 
$\left.\mathrm{s}^{-1}\right)$ with no significant difference with T5 $(4.83 \mu \mathrm{M}$ $\left.\mathrm{CO}_{2} \mathrm{~m}^{-2} \mathrm{~s}^{-1}\right)$ and T6 $\left(4.23 \mu \mathrm{M} \mathrm{CO}_{2} \mathrm{~m}^{-2} \mathrm{~s}^{-1}\right)$ (Table 3). Photosynthesis rate in plants of $\mathrm{T} 4$ and $\mathrm{T} 5$ indicated significant higher values compared to plants of $\mathrm{T} 1$ (3.69 $\left.\mu \mathrm{M} \mathrm{CO}_{2} \mathrm{~m}^{-2} \mathrm{~s}^{-1}\right), \mathrm{T} 3\left(3.58 \mu \mathrm{M} \mathrm{CO}_{2} \mathrm{~m}^{-2} \mathrm{~s}^{-1}\right)$ and T2 (3.27 $4.23 \mu \mathrm{M} \mathrm{CO}_{2} \mathrm{~m}^{-2} \mathrm{~s}^{-1}$. Plants of T6 showed no significant difference in photosynthesis rate (4.23 $\left.\mu \mathrm{M} \mathrm{CO}_{2} \mathrm{~m}^{-2} \mathrm{~s}^{-1}\right)$ compared to plants of T1 and T3.

Quantum efficiency of PSII. Quantum efficiency of PSII was significantly reduced in the infected treatments (Table 3). Plants of T2 indicated the lowest quantum efficiency PSII with $0.52 \mathrm{Fv} / \mathrm{Fm}$ compared to plants of T4 $(0.65 \mathrm{Fv} / \mathrm{Fm}), \mathrm{T} 5(0.72 \mathrm{Fv} / \mathrm{Fm})$ and T6 $(0.65 \mathrm{Fv} / F \mathrm{~m})$. The highest value of quantum efficiency PSII was recorded by plants of T1 (0.76 $\mathrm{Fv} / \mathrm{Fm})$ and T3 $(0.79 \mathrm{Fv} / \mathrm{Fm})$ with no significant difference with plants of $\mathrm{T} 5$.

Relative leaf chlorophyll content. There was no significant difference in relative leaf chlorophyll content between plants of T1 $\left(48.15 \mu \mathrm{g} \mathrm{cm}^{-2}\right)$, T6 $(45.49$ $\left.\mu \mathrm{g} \mathrm{cm}^{-2}\right)$, T3 $\left(44.71 \mu \mathrm{g} \mathrm{cm}^{-2}\right)$, and T5 $\left(43.83 \mu \mathrm{g} \mathrm{cm}^{-2}\right)$
(Table 3). There was also no significant difference between plants of T2 $\left(33.91 \mu \mathrm{g} \mathrm{cm}^{-2}\right)$ and T4 $(33.26$ $\mu \mathrm{g} \mathrm{cm}^{-2}$ ). Plants of T1, T3, T5, and T6 showed highly significant difference in relative chlorophyll content compared to plants of $\mathrm{T} 2$ and $\mathrm{T} 4$.

\section{Expression of Defense-related Gene $\beta-1,3-$ Glucanase}

Figure 5 shows gel image on the expression of housekeeping gene GAPDH and defenserelated gene $\beta$-1,3-glucanase and Table 4 shows the measured intensity of each expressed band. The $\beta$-1,3-glucanase was expressed at the highest level in plants of T5 $\left(0.50 \mu \mathrm{g}\right.$ a.i. $\mathrm{ml}^{-1}$ pyraclostrobin $)$ at $0,2,4$, and 8 months after inoculation with band intensity of $3.43,3.64,0.80$, and 1.53 , respectively. This phenomenon may be due to the sufficient amount of pyraclostrobin application and at the right time of every two months. Plants of T4 (0.25 $\mu \mathrm{g}$ a.i. $\mathrm{ml}^{-1}$ pyraclostrobin) revealed fluctuating $\beta$-1,3-glucanase expression started with the low expression at 0 month after inoculation (MAI) (0.17),

TABLE 3. PHYSIOLOGICAL ANALYSIS OF OIL PALM SEEDLINGS TREATED WITH FUNGICIDES, INOCULATED AND UNINOCULATED WITH Ganoderma boninense AT EIGHT MONTHS AFTER INOCULATION

\begin{tabular}{|c|c|c|c|c|}
\hline Treatments $^{\mathrm{a}}$ & Oil palm status & $\begin{array}{l}\text { Photosynthesis rate } \\
\qquad\left(\mu \mathrm{M} \mathrm{CO} \mathrm{CO}_{2} \mathrm{~m}^{-2} \mathrm{~s}^{-1}\right)^{\mathrm{b}}\end{array}$ & $\begin{array}{c}\text { PSII quantum } \\
\text { efficiency }(F v / F m)^{b}\end{array}$ & $\begin{array}{l}\text { Relative leaf chlorophyll } \\
\text { content }\left(\mu \mathrm{g} \mathrm{cm}^{-2}\right)^{\mathrm{b}}\end{array}$ \\
\hline $\mathrm{T} 1$ & Healthy & $3.69 \pm 0.40 b$ & $0.76 \pm 0.07 a$ & $48.15 \pm 2.03 a$ \\
\hline $\mathrm{T} 3$ & & $3.58 \pm 0.27 b$ & $0.79 \pm 0.01 \mathrm{a}$ & $44.71 \pm 1.33 a$ \\
\hline $\mathrm{T} 2$ & Disease & $3.27 \pm 0.32 b$ & $0.52 \pm 0.02 c$ & $33.91 \pm 1.90 b$ \\
\hline $\mathrm{T} 4$ & & $4.95 \pm 0.27 a$ & $0.65 \pm 0.00 b$ & $33.26 \pm 2.90 b$ \\
\hline $\mathrm{T} 5$ & & $4.83 \pm 0.39 a$ & $0.72 \pm 0.02 \mathrm{ab}$ & $43.83 \pm 2.86 a$ \\
\hline T6 & & $4.23 \pm 0.67 a b$ & $0.65 \pm 0.07 b$ & $45.49 \pm 2.31 a$ \\
\hline
\end{tabular}

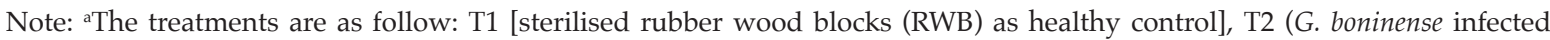
RWB as disease control), T3 (sterilised RWB $+0.25 \mu \mathrm{g} \mathrm{ml}^{-1}$ of pyraclostrobin as pyraclostrobin control), T4 $\left(0.25 \mu \mathrm{g} \mathrm{ml}{ }^{-1}\right.$ of pyraclostrobin + G. boninense infected RWB as $\mathrm{EC}_{50}$ treatment), $\mathrm{T} 5\left(0.5 \mu \mathrm{g} \mathrm{ml}^{-1}\right.$ of pyraclostrobin + G. boninense infected RWB as $\mathrm{EC}_{75}$ treatment), and $\mathrm{T} 6\left(0.1 \mu \mathrm{g} \mathrm{ml}{ }^{-1}\right.$ of hexaconazole as positive control).

${ }^{\mathrm{b}}$ Means with same letter in the same column are not significantly different $(\mathrm{P} \leq 0.05)$ by Least Significance Different (LSD).

TABLE 4. EXPRESSION OF $\beta-1,3-G L U C A N A S E$ OF OIL PALM SEEDLINGS TREATED WITH FUNGICIDES, INOCULATED AND UNINOCULATED WITH Ganoderma boninense AT EIGHT MONTHS AFTER INOCULATION

\begin{tabular}{|c|c|c|c|c|c|c|}
\hline \multirow[t]{2}{*}{ Treatments ${ }^{\mathrm{a}}$} & \multirow[t]{2}{*}{ Oil palm status } & \multicolumn{5}{|c|}{ Month $^{b, c}$} \\
\hline & & 0 & 2 & 4 & 6 & 8 \\
\hline $\mathrm{T} 1$ & Healthy & $1.00 \mathrm{~b}$ & $1.78 \mathrm{~b}$ & $0.37 \mathrm{~b}$ & $0.43 c$ & $0.47 \mathrm{C}$ \\
\hline $\mathrm{T} 3$ & & $1.00 \mathrm{~b}$ & $1.04 \mathrm{c}$ & $0.10 \mathrm{~d}$ & $0.51 b$ & $0.17 \mathrm{c}$ \\
\hline $\mathrm{T} 2$ & Disease & $0.14 \mathrm{~d}$ & $0.14 \mathrm{e}$ & $0.13 \mathrm{~d}$ & $0.27 \mathrm{~d}$ & $0.89 \mathrm{~b}$ \\
\hline $\mathrm{T} 4$ & & $0.17 \mathrm{~d}$ & $0.87 \mathrm{~d}$ & $0.15 c$ & $0.51 b$ & $0.16 \mathrm{~d}$ \\
\hline $\mathrm{T} 5$ & & $3.43 a$ & $3.64 a$ & $0.80 \mathrm{a}$ & $0.13 \mathrm{e}$ & $1.53 a$ \\
\hline T6 & & $0.55 c$ & $0.19 \mathrm{e}$ & $0.12 d$ & $0.73 a$ & $0.11 \mathrm{e}$ \\
\hline
\end{tabular}

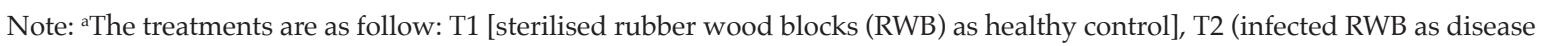
control), T3 (sterilised RWB $+0.25 \mu \mathrm{g} \mathrm{ml}^{-1}$ of pyraclostrobin as pyraclostrobin control), T4 $\left(0.25 \mu \mathrm{g} \mathrm{ml} \mathrm{m}^{-1}\right.$ of pyraclostrobin + infected RWB as $\mathrm{EC}_{50}$ treatment), T5 $\left(0.5 \mu \mathrm{g} \mathrm{ml} \mathrm{m}^{-1}\right.$ of pyraclostrobin + infected $\mathrm{RWB}$ as $\mathrm{EC}_{75}$ treatment), and $\mathrm{T} 6{ }^{0} 0.1 \mu \mathrm{g} \mathrm{ml}^{-1}$ (manufacture's recommendation) of hexaconazole as positive control].

${ }^{b}$ Month 0 means four days after challenging the seedlings with G. boninense.

cValues are mean of three replicates and in unit of net intensity data for $\beta$-1,3-glucanase corrected to glycerialdehyde3-phosphate dehydrogenase (GAPDH) gene and normalise to $0 \mathrm{hr}$. Means with same letter in the same column are not significantly different $(\mathrm{P} \leq 0.001)$ by Least Significance Different (LSD). 

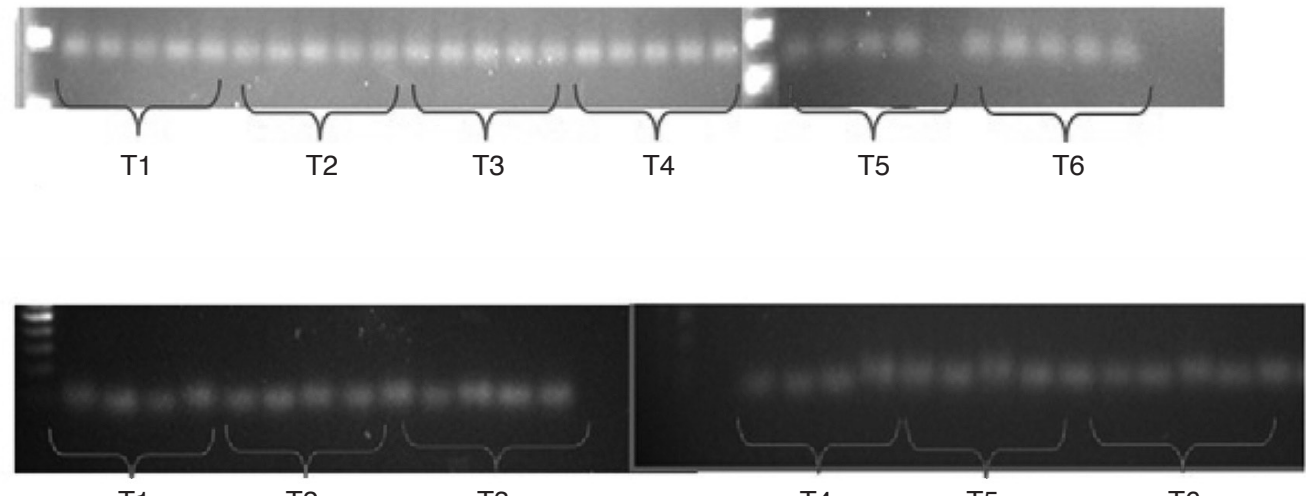

T1

T2

T3

T4

T5

T6

Figure 5. Expression of housekeeping gene GAPDH (a) and defense-related gene $\beta$-1,3-glucanase (b). The treatments are as follow: T1 [sterilised rubber wood blocks (RWB) as healthy control], T2 (G. boninense infected RWB as disease

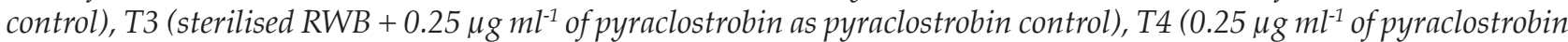

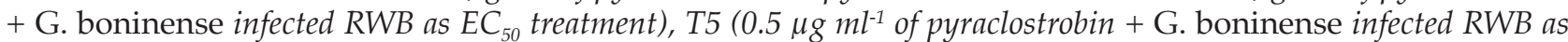
$E C_{75}$ treatment), and T6 (0.1 $\mu \mathrm{g} \mathrm{ml}^{-1}$ of hexaconazole $+\mathrm{G}$. boninense infected $R W B$ as positive control).

peaked at 2 MAI (0.87), decreased back to baseline at $4 \mathrm{MAI}(0.15)$, slightly increased at $6 \mathrm{MAI}(0.51)$, and dropped back to baseline at $8 \mathrm{MAI}(0.16)$.

In plants of positive control (T2), $\beta$-1,3-glucanase expression was low at 0, 2, 4, and $6 \mathrm{MAI}(0.14,0.14$, 0.13 and 0.27 , respectively), and peaked at $8 \mathrm{MAI}$ (0.89). The $\beta$-1,3-glucanase expression in plants of T6 peaked at 0 MAI (0.55) and 6 MAI (0.73) where the gene was down-regulated at 2 MAI (0.19), 4 MAI (0.12) and 8 MAI (0.11). Plants of T1 (negative control) showed high $\beta$-1,3-glucanase expression at 0 MAI (1.00) and peaked at 2 MAI (1.78) before decreased to moderate level of expression at 4 , 6 and 8 MAI (0.37, 0.43 and 0.47 , respectively). Plants of T3 (pyraclostrobin control) showed high $\beta$-1,3-glucanase expression at 0 MAI (1.00) and 2 MAI (1.04) before decreased at 4 MAI (0.10), then increased at $6 \mathrm{MAI}(0.51)$, and dropped again at 8 MAI (0.10) to the level similar to that at 4 MAI.

\section{DISCUSSION}

In this study, in vitro assessment revealed that mycelial growth of $G$. boninense was highly suppressed by both pyraclostrobin and hexaconazole at different concentrations with fungistatic activity. A previous report studied on azoxystrobin tested against Armillaria mellea (causing white root rot of vine) also indicated fungistatic effect (Aguín et al., 2006). Inhibition of $G$. boninense mycelial growth may be caused by pyraclostrobin's mode of action in inhibiting fungal mitochondrial respiration, thus inhibition of electric transport chain in ATP production of pathogenic fungi, and eventually blocking cytochrome bc1 complex (Bartlett et al., 2002).

For in vivo experiment, pyraclostrobin concentrations at $\mathrm{EC}_{50}$ and $\mathrm{EC}_{75}$ were used to evaluate their protecting activities on oil palm seedlings against $G$. boninense. Eight months after inoculation, the low DI, DS, and AUDPC demonstrated that application of pyraclostrobin at $\mathrm{EC}_{75}$ had significantly reduced BSR damage compared to seedlings treated with pyraclostrobin at $\mathrm{EC}_{50}$, and hexaconazole. These results indicated that the infected seedlings have acquired some kind of curative effect after infection. Previous studies have also indicated that pyraclostrobin has the ability to suppress plant pathogenic fungi such as Sclerotinia, causing stem rot of pepper (Zitter, 2014), anthracnose, causing fruit rot of strawberry (Wedge et al., 2007), Phytophthora infestans, causing late blight of tomato (Nelson, 2008; Wang et al., 2014), and Pythium, root rot of cereals (Dyer et al., 2012). Wang et al. (2014) also demonstrated that application of combination of fluopicolide and pyraclostrobin at $\mathrm{EC}_{50}$ at ratio of $1: 4(\mathrm{w} / \mathrm{w})$ on potato infected with late blight showed protective and curative activities. Pyraclostrobin has strong inhibitory effects on fungal pathogens at all major stages of their life cycles such as spore germination, germ tube elongation, mycelial growth, and sporulation (Karadimos et al., 2005).

Pyraclostrobin has an excellent record in enhancing plant growth (Joshi et al., 2014). A previous study had also indicated that Kresoximmethyl (fungicide class strobilurin) increased plant growth, yield and photosynthesis rate of apple infected by scab disease (Kunz et al., 1998). In this study, disease infected oil palm seedlings treated with pyraclostrobin also demonstrated significant increase in plant height, bole diameter, fresh weight, and root fresh weight, which further support that pyraclostrobin had positive effect on plant growth of oil palm. The seedlings treated with pyraclostrobin at $\mathrm{EC}_{75}$ revealed the highest enhancement of 
plant growth compared to other disease infected treatments. The increase in plant growth of oil palm seedlings may be due to the ability of pyraclostrobin in improving plant physiology and acts as a plant growth regulator (European Food Safety Authority, 2010).

In general, seedlings treated with pyraclostrobin at $\mathrm{EC}_{75}$ and hexaconazole gave positive effects on plant physiology. Previous study also reported that hexaconazole may exert stimulant effects on plant physiology (Petit et al., 2012). Photosynthesis rates were higher in seedlings treated with pyraclostrobin at $\mathrm{EC}_{75}, \mathrm{EC}_{50}$, and hexaconazol with no significant difference between the three treatments. A common response to pathogen infection is a reduction in the rate of photosynthesis in infected leaves (Walters, 2015), which was observed in the positive control (T2) seedlings in this study. Quantum efficiency of PSII measured by chlorophyll fluorescence is commonly used in early detection of disease infected plants (Bürling et al., 2011). In this study, positive control (T2) oil palm seedlings demonstrated the lowest quantum efficiency PSII value of $0.52 \mathrm{Fv} /$ Fm showing that the seedlings were under stress condition caused by injury at the root affected by BSR infection. Relative chlorophyll content also showed that there was no significant difference between seedlings treated with pyraclostrobin at $\mathrm{EC}_{75}$ (T5) and hexaconazole (T6), pyraclostrobin only control (T3) and negative control (T1) seedlings but they were significantly higher than plants of positive control (T2) and pyraclstrobin at $\mathrm{EC}_{50}(\mathrm{~T} 4)$.

The $\beta$-1,3-glucanase was differently expressed in response to infection by $G$. boninense in both treated and untreated oil palm seedlings. However, the time of expression and magnitude of expression varied between the fungicide treatments. Pyraclostrobin at $\mathrm{EC}_{75}$ induced early expression of $\beta$-1,3-glucanase in oil palm seedlings ( 0 and 2 MAI) compared to expression in only Ganoderma boninense infected seedlings (8 MAI). Moreover, $\beta$-1,3-glucanase expression in seedlings treated with pyraclostrobin at $\mathrm{EC}_{75}$ was the highest level at all months after inoculation except for month 6 and this correlated well with the lowest disease infection (DI, DS and AUDPC) observed in this treatment. Previous study also reported that the level of $\beta-1,3-$ glucanase expression was often correlated with the degree of resistance of Hevea clones against Phytophthora meadii (Thanseem et al., 2005). The fluctuation of $\beta$-1,3-glucanase gene expression over time demonstrated in some treatments in this study is common in plants (Eugenia Rivera et al., 2002) in terms of interaction with the pathogen. When plants recognise pathogens, they will activate various defense systems and usually produced two peaks along the infection period (Kwan et al., 2015). The $\beta$-1,3-glucanases help plants to defend against fungal pathogens either alone or in association with chitinases and other anti-fungal proteins (Balasubramanian et al., 2012).

\section{CONCLUSION}

Both pyraclostrobin at $0.25,0.50$, and $0.75 \mu \mathrm{g}$ a.i. $\mathrm{ml}^{-1}$ and hexaconazole at $0.05,0.10$, and $0.15 \mu \mathrm{g}$ a.i. $\mathrm{ml}^{-1}$ demonstrated high PIRG inhibition against $G$. boninense in vitro (50\%-80\%). In vivo study using pyraclostrobin at $\mathrm{EC}_{75}$ verified its ability to control BSR disease with high efficacy demonstrated by the lowest AUDPC. Generally, higher plant growth (increment of height, bole diameter, fresh weight and root mass) and positive effects on plant physiology (photosynthesis rate, PSII quantum efficiency and relative leaf chlorophyll content) were observed in seedlings treated with pyraclostrobin at $\mathrm{EC}_{75}$. Pyraclostrobin application at $\mathrm{EC}_{75}$ had the ability to induce high level of $\beta$-1,3-glucanase expression at early stage in the infected seedlings which may play an important role to suppress the disease. This study revealed that pyraclostrobin at $\mathrm{EC}_{75}$ has the potential to control BSR disease of oil palm and provides a more sustainable alternative compared to hexaconazole. However, a study using mature oil palm in the field is required to confirm these results.

\section{ACKNOWLEDGEMENT}

This project was supported by Research University Grant Scheme (RUGS) Initiative 6, Universiti Putra Malaysia, 2011-2012.

\section{REFERENCES}

Aguín, O; Mansilla, J P and Sainz, M J (2006). In vitro selection of an effective fungicide against Armillaria mellea and control of white root rot of grapevine in the field. Pest. Manag. Sci., 62(3): 223-228.

Azura, A N; Yusoff, M; Tan, G; Jegadeesh, R; Appleton, D and Vikineswary, S (2016). Streptomyces sanglieri which colonised and enhanced the growth of Elaeis guineensis Jacq. seedlings was antagonistic to Ganoderma boninense in in vitro studies. J. Industrial. Microbiol. Biotechnol., 43(4): 485-493.

Balasubramanian, V; Vashisht, D; Cletus, J and Sakthivel, N (2012). Plant $\beta$-1, 3-glucanases: Their biological functions and transgenic expression against phytopathogenic fungi. Biotech. Let., 34(11): 1983-1990.

Bartlett, D W; Clough, J M; Godwin, J R; Hall, A A; Hamer, M and Parr Dobrzanski, B (2002). The strobilurin fungicides. Pest. Manag. Sci., 58(7): 649-662. 
Breton, F; Hasan, Y; Lubis, Z and De Franqueville, $H$ (2005). Characterization of parameters for the development of an early screening test for basal stem rot tolerance in oil palm progenies. Proc. of the PIPOC 2005 International Palm Oil Congress Agriculture, Biotechnology \& Sustainability Conference. MPOB, Bangi. p. 971.

Bürling, K; Hunsche, M and Noga, G (2011). Use of blue-green and chlorophyll fluorescence measurements for differentiation between nitrogen deficiency and pathogen infection in winter wheat. Plant Pathol. J., 168(14): 1641-1648.

Campbell, C L and Madden, L V (1990). Introduction to Plant Disease Epidemiology. John Wiley \& Sons, New York. p. 532.

Chen, Z Y; Goh, Y K; Goh, Y K and Goh, K J (2017). Life expectancy of oil palm (Elaeis guineensis) infected by Ganoderma boninense in coastal soils, Malaysia: A case study. Arch. Phytopathol. Plant Protect., 50(1112): $598-612$

Cota, I; Troncoso-Rojas, R; Sotelo-Mundo, R; Sánchez-Estrada, A and Tiznado-Hernández, M (2007). Chitinase and $\beta$-1, 3-glucanase enzymatic activities in response to infection by Alternaria alternata evaluated in two stages of development in different tomato fruit varieties. Scientia Horticul., 112(1): 42-50.

Dyer, A; Johnston, J; Tharp, C and Burrows, M (2012). Small grain seed treatment guide. Montana State University Extension. Accessed on 12 June 2013.

Eugenia Rivera, M; Codina, J C; Olea, F; De Vicente, A and Pérez-García, A (2002). Differential expression of $\beta$-1,3-glucanase in susceptible and resistant melon cultivars in response to infection by Sphaerotheca fusca. Physio. Mol. Plant. Pathol., 61(5): 257-265.

European Food Safety Authority (2010). Modification of the existing MRLs for pyraclostrobin in tomatoes, aubergines, globe artichokes and celeriac. EFSA J., 8(6): 1630.

Govender, N T; Mahmood, M; Seman, I A and Wong, M Y (2017). The phenylpropanoid pathway and lignin in defense against Ganoderma boninense colonized root tissues in oil palm (Elaeis guineensis Jacq.). Front. Plant Sci., 8: 1395.

Hara, K; Pangkey, H; Osatomi, K; Yatsuda, K; Hagiwara, A; Tachibana, K and Ishihara, T (1997). Some properties of $\beta$-1, 3-glucan hydrolyzing enzymes from the rotifer Brachionus plicatilis. Hydrogeol. J., 358: 89-94.
Hasan, Y and Turner, P (1998). The comparative importance of different oil palm tissues as infection sources for basal stem rot in replantings. The Planter, 74 (864): 119-135.

Horvath, D M; Huang, D J and Chua, N H (1998). Four classes of salicylate-induced tobacco genes. Mol. Plant Microbe Interact., 11(9): 895-905.

Hushiarian, R; Yusof, N A and Dutse, S W (2013). Detection and control of Ganoderma boninense: Strategies and perspectives. SpringerPlus, 2(1): 555.

Idris, A (2007). Managing the Ganoderma Basal Stem Rot in Oil Palm Plantation through Sanitation and Fungicidal Treatment. MPOB, Bangi. p. 322.

Idris, A; Ariffin, D; Basri, M; Hayakawa, S; Noorhasimah, I and Yamaoka, M (2003). PCR Technique for Detection of Ganoderma. MPOB, Bangi. p. 3.

Joshi, J; Sharma, S and Guruprasad, K (2014). Foliar application of pyraclostrobin fungicide enhances the growth, rhizobial-nodule formation and nitrogenase activity in soybean (var. JS-335). Pesti. Biochem. Physiol., 114: 61-66.

Karadimos, D A; Karaoglanidis, G S and TzavellaKlonari, K (2005). Biological activity and physical modes of action of the Qo inhibitor fungicides trifloxystrobin and pyraclostrobin against Cercospora beticola. Crop Prot., 24(1): 23-29.

Keen, $\mathrm{N}$ and Yoshikawa, M (1983). $\beta-1$, 3-Endoglucanase from soybean releases elicitoractive carbohydrates from fungus cell walls. Plant Physiol., 71(3): 460-465.

Kunz, S; Lutz, B; Deising, H and Mendgen, K (1998). Assessment of sensitivities to anilinopyrimidineand strobilurin-fungicides in populations of the apple scab fungus Venturia inaequalis. J. Phytopathol., 146(5-6): 231-238.

Kwan, Y M; Meon, S; Ho, C L and Wong, M Y (2015). Cloning of nitric oxide associated 1 (NOA1) transcript from oil palm (Elaeis guineensis) and its expression during Ganoderma infection. J. Plant Physiol., 174: 131-136.

Kwan, Y M; Meon, S; Ho, C L and Wong, M Y (2016). Selection of reference genes for quantitative realtime PCR normalization in Ganoderma-infected oil palm (Elaeis guineensis) seedlings. Aust. Plant Path., 45(3): 261-268.

Liu, L; Kloepper, J and Tuzun, S (1995). Induction of systemic resistance in cucumber against bacterial angular leaf spot by plant growth-promoting rhizobacteria. Phytopathology, 85(8): 843-847. 
MPOB (2016). Overview of the Malaysian oil palm industry. http:/ / www.mpob.gov.my/

Mcdougall, P (2004). AgriServices, Products Section 2004 Market. p. 253-260.

Naher, L; Yusuf, U K; Ismail, A; Tan, S G and Mondal, M (2013). Ecological status of' Ganoderma and basal stem rot disease of oil palms (Elaeis guineensis Jacq.). Aust. J. Crop Sci., 7(11): 1723.

Nelson, S C (2008). Late Blight of Tomato (Phytophthora infestans), PD-45. p. 10.

Neumann, S and Jacob, F (1995). Principles of uptake and systemic transport of fungicides within the plant. Modern Selective Fungicides (Lyr, H ed.). p. 54-73.

Oettli, P; Behera, S K and Yamagata, T (2018). Climate based predictability of oil palm tree yield in Malaysia. Sci. Rep., 8(1): 2271.

Petit, A N; Fontaine, F; Vatsa, P; Clément, C and Vaillant-Gaveau, N (2012). Fungicide impacts on photosynthesis in crop plants. Photosynth. Res., 111(3): 315-326.

Ponstein, A S; Bres-Vloemans, S A; Sela-Buurlage, M B; Van Den Elzen, P J; Melchers, L S and Cornelissen, B J (1994). A novel pathogen- and wound-inducible tobacco (Nicotiana tabacum) protein with antifungal activity. Plant Physiol., 104(1): 109-118.

Rivera, M E; Codina, J C; Olea, F; De Vicente, A and Pérez-García, A (2002). Differential expression of $\beta$-1, 3-glucanase in susceptible and resistant melon cultivars in response to infection by Sphaerotheca fusca. Physiol. Mol. Plant Pathol., 61(5): 257-265.

Sadrati, N; Daoud, H; Zerroug, A; Dahamna, S and Bouharati, S (2013). Screening of antimicrobial and antioxidant secondary metabolites from endophytic fungi isolated from wheat (Triticum durum). J. Plant Protec. Res., 53(2): 128-136.

Sahebi, M; Hanafi, M M; Wong, M Y; Idris, A S; Azizi, P; Jahromi, M F; Shokryazdan, P; Abiri, R and Mohidin, H (2015). Towards immunity of oil palm against Ganoderma fungus infection. Acta Physiol. Plant., 37(10): 195.

Sargolzaei, M; Ho, C L and Wong, M Y (2016). Characterization of novel type I ribosomeinactivating proteins isolated from oil palm (Elaeis guineensis) inoculated with Ganoderma boninense, the causal agent of basal stem rot. Physiol. Mol. Plant Pathol., 94: 53-61.

Sathyapriya, H; Sariah, M; Siti Nor Akmar, A and Wong, M (2012). Root colonisation of Pseudomonas aeruginosa strain UPMP 3 and induction of defencerelated genes in oil palm (Elaeis guineensis). Ann. Appl. Biol., 160(2): 137-144.

Stintzi, A; Heitz, T; Prasad, V; WiedemannMerdinoglu, S; Kauffmann, S; Geoffroy, P; Legrand, M and Fritig, B (1993). Plant pathogenesis-related proteins and their role in defense against pathogens. Biochimie, 75(8): 687-706.

Subagio, A and Foster, H (2003). Implications of Ganoderma disease on loss in stand and yield production of oil palm in North Sumatra. Proc. of the MAPPS Conference, 2003. p. 12.

Tan, Y C; Ang, C L; Wong, M Y and Ho, C L (2016a). Oil palm defensin: A thermal stable peptide that restricts the mycelial growth of Ganoderma boninense. Protein Pept. Lett., 23(11): 994-1002.

Tan, Y C; Ho, W Y; Alitheen, N B; Wong, M Y and Ho, C L (2016b). Cloning and expression of oil palm (Elaeis guineensis Jacq.) type 2 ribosome inactivating protein in Escherichia coli. Int. J. Peptide Res. Therapeutics, 22(1): 37-44.

Tan, Y C; Wong, M Y and Ho, C L (2015). Expression profiles of defence related cDNAs in oil palm (Elaeis guineensis Jacq.) inoculated with mycorrhizae and Trichoderma harzianum Rifai T32. Plant. Phys. Biochem., 96: 296-300.

Tan, Y C; Yeoh, K A; Wong, M Y and Ho, C L (2013). Expression profiles of putative defence-related proteins in oil palm (Elaeis guineensis) colonized by Ganoderma boninense. J. Plant Physiol., 170(16): 14551460.

Teh, K and Sariah, M (1999). Inoculation system for testing pathogenicity of Ganoderma boninense on oil palms. Fourth MAAPS International Conference on J. Plant Protection in the Tropics. p. 142-145.

Thanseem, I; Joseph, A and Thulaseedharan, A (2005). Induction and differential expression of $\beta-1$, 3-glucanase mRNAs in tolerant and susceptible Hevea clones in response to infection by Phy tophthora meadii. Tree Physiol., 25(11): 1361-1368.

Van Loon, L and Bakker, P (2003). Signalling in rhizobacteria-plant interactions. Root Ecology. Springer. p. 297-330.

Walters, D R (2015). Physiological Responses of Plants to Attack. First edition. John Wiley \& Sons, Ltd. 248 pp.

Wang, W Q; Zhang, P; Meng, R J; Zhao, J J; Huang, Q L; Han, X Y; Ma, Z Q and Zhang, X F (2014). Fungitoxicity and synergism of mixtures of fluopicolide and pyraclostrobin against Phytophthora infestans. Crop Protec., 57: 48-56. 
Wedge, D E; Smith, B J; Quebedeaux, J P and Constantin, R J (2007). Fungicide management strategies for control of strawberry fruit rot diseases in Louisiana and Mississippi. Crop Protec., 26(9): 1449-1458.

Wong, L; Bong, C F J and Idris, A (2012). Ganoderma species associated with basal stem rot disease of oil palm. Am. J. Applied Sci., 9(6): 879-885.
Yeoh, KA; Othman, A; Meon, S; Abdullah, F and Ho, C L (2012). Sequence analysis and gene expression of putative exo- and endo-glucanases from oil palm (Elaeis guineensis) during fungal infection. J. Plant Physiol., 169(15): 1565-1570.

Zitter, T A (2014). Tomato, Eggplant and Pepper Fungicides Labeled and Rates. Department of Plant Pathology, Cornell University, Ithaca, NY. p. 2-4. 